\title{
Early Identifications of Apollo with the Physical Sun in Ancient Greece Tradition and Interpretation
}

\section{Tomislav Bilić}

Archaeological Museum in Zagreb

tbilic@amz.hr

Received August 2019 | Accepted February 2020

\begin{abstract}
It appears that Apollo's identification with the physical sun is predominantly understood in modern scholarship as a philosophical interpretation of a traditional religious belief. More precisely, it is often understood as an application of physical allegoresis on the tenets of traditional religion and thus attributed to a later stratum of Greek thought. A new evaluation of ancient evidence presented here reveals that the Apollo-sun identification was present in Greek ethnographic context from the earliest period and cannot be reduced to a philosophical reinterpretation of traditional myth and religion. At the same time, the authors interested in the interpretation of traditional religion in terms of natural philosophy were especially prone to use the Apollo-sun identification in their works, since it was able to provide substantial support for their hermeneutic approach.
\end{abstract}

\section{Keywords}

Apollo - Helios - sun - traditional religion - philosophical interpretation - myth

\section{Introduction}

It is not surprising that a Greek god is a complex and dynamic entity. Centuries of development could only result in various influences, coming from different areas and/or epochs, forming and reshaping the appearance of a particular 
deity. This phenomenon is aptly illustrated in Parker's 'snowball' theory of Greek gods, which acknowledges an evolutionary development of gods through time by the process of amalgamation of various functions and powers. ${ }^{1}$ Apollo is no exception, ${ }^{2}$ and a formulation of "an underlying unity" behind his many and diverse functions, both in synchronic and diachronic sense, would represent only a mirage. ${ }^{3}$ These observations are in line with the currently prevailing scholarly opinion, embodied in a change from "a mythical and monolithic" model in the $19^{\text {th }}$ century studies on Apollo to "a historicizing concept based on evolution and amalgamation" in the $20^{\text {th }}$ (and $21^{\text {st }}$ ) century. ${ }^{4}$ At the same time, this approach belongs to a larger trend in the studies of myth and religion, characterised by a polyparadigmatic perspective. ${ }^{5}$ But in the eclectic approaches that characterize these studies a clear recognition of one particular facet of Apollo's functions seems to be missing: his identification with the sun (god), which once seemed so indisputable to Roscher. ${ }^{6}$

The 'snowball' model presupposes that it is in theory possible to discern different constituent elements in the nexus of functions represented by a particular deity. Thus, for example, Burkert recognized several components in the earliest Apollo worship. ${ }^{7}$ But he found no place for the sun in his analysis of the early worship of Apollo, ${ }^{8}$ and one of the most conspicuous characteristics of the dominant paradigm - to the formation of which Burkert certainly contributed - in the studies of Apollo is precisely the complete avoidance of the sun. Indeed, Apollo's solar connections, especially in the Archaic period, are largely dismissed in modern scholarship. ${ }^{9}$ Dissenting voices that are occasionally raised appear only in Festschriften, congress proceedings or similar

\footnotetext{
${ }^{1}$ Parker 2011, 86. Similarly, Iles Johnston 2018, 156-159 treats Greek gods as accretive characters, whose various traits were drawn from their different instantiations in myths and other media.

${ }^{2}$ West 2007, 148.

${ }^{3}$ Graf 2009, 146.

${ }^{4}$ Versnel 1994, 293.

${ }^{5}$ Versnel 1994, 7, 11-14, 19, 86-87, 89; Dowden 1992, 16, 24-25; Csapo 2005, 7-8, cf. 290-291; Bremmer 2011, 539; Parker 2011, 22, 25.

${ }^{6}$ Roscher 1884-1890, 422. Cf. Burkert 1985, 406 n. 55; Versnel 1994, 291-292.

${ }^{7}$ Burkert 1985, 144.

${ }^{8}$ Cf. Konaris 2016, 296. As Konaris 2016, 296 n. 54 notes in his discussion of Apollo in Greek Religion, Burkert mentions the solar identification of the god only in the very last sentence (Burkert 1985, 149).

${ }^{9}$ See e.g. Fontenrose 1978, xiv; Graf 2009 (a monograph devoted specifically to the deity, where Apollo's solar connections are discussed only in the section titled “Apollo's flourishing aftermath”); Gantz 1993, 87-88.
} 
outlets. ${ }^{10}$ So what has happened between Roscher and Burkert and Graf that so completely changed the scholarly outlook on the Apollo-sun identification?

Before proceeding to this discussion, I must clarify the term 'identification' used in the title and throughout this paper. It would be more correct to describe the presence of solar traits in Greek understandings of Apollo in terms of interacting conceptual domains. ${ }^{11}$ As a complex entity, a conceptual focus around which "cluster[ed] various ideas, images, and narrative motifs", 12 Apollo attracted a number of elements belonging to different conceptual domains as he developed through time. One of these domains was, from an early period, as the evidence presented in this paper will show, an interest in the sun and its behaviour. ${ }^{13}$ 'The Apollo-sun identification' should thus be understood as referring to an accretion of elements from the solar domain to a complex member of the Greek polytheistic system, rather than a one-to-one identification of one deity with another, or the deity with the physical sun.

Recent scholarship has found a plausible explanation, or a number of explanations, for the notable omission of Apollo's solar affiliations in modern studies, anchored on the one hand in objective criticism, accompanied by a gradual change of scholarly focus and interpretative approaches, but on the other hand ideologically motivated. Thus the position of classical scholars is at least partly explicable as a reaction to the solar-mythology (or naturemythology in a wider sense) paradigm that dominated the $19^{\text {th }}$-century discussions on the subject, ${ }^{14}$ which culminated in W.H. Roscher's work, especially his famous Mythologisches Lexikon. ${ }^{15}$ In addition, with the move from a substantive to a socio-cultural framework of interpretation of religion, the 'physical' content of beliefs as exemplified in myths was overshadowed by other concerns, such as the role of cult and its relevance to the worshippers in chronologically sensitive contexts. ${ }^{16}$ This approach is exemplified in the initiation paradigm, which now itself appears to be on the wane, but which exercised considerable influence on Apollo-studies in its heyday. ${ }^{17}$ On the other hand, some less objective reasons may lie behind the unusually spirited dismissal of the Apollo-sun

\footnotetext{
${ }^{10}$ E.g. Boyancé 1966; Moreau 1996.

${ }^{11}$ For this concept see Buxton 2017, 55, 59.

${ }^{12}$ Mondi 1990, 145, 148, 159.

${ }^{13}$ A complementary interest in calendrical concerns, especially prominent in the cluster of myths and cults focusing on the 'Hyperborean Apollo', will be treated elsewhere.

${ }^{14}$ E.g. Farnell 1907, 136, followed by a passionate and often hasty dismissal of every possible association of Apollo with the sun, at 136-144.

${ }^{15}$ Versnel 1994, 289-292; Konaris 2010, 484-487; 2016, 123-130.

${ }^{16}$ Versnel 1994, 7-11.

${ }^{17}$ For the rise of the initiation paradigm and its supplanting of the earlier fertility paradigm see Graf 2003, 5-6, 19-20; for its diminishing relevance see ibid. 20.
} 
identification. Thus Farnell, whose rejection of this identification perhaps exercised the greatest influence on future scholarship, ${ }^{18}$ was adamant to remove the traces of "transparent nature-worship" from Greek religion, which he believed operated on a wholly different - and, clearly, higher-level of "concrete, moral and supra-physical" deities. ${ }^{19}$ The roots of this perspective can be found in K.O. Müller's ideologically loaded dismissal of the Apollo-sun identification, who relegated 'nature-worship' to 'Orientals' as unworthy of his highly cultured Dorians. ${ }^{20}$ A parallel case of a contemporary anti-Oriental bias appears in the $19^{\text {th }}$ /early $20^{\text {th }}$-century classicists' understanding of the Roman cult of Sol, which they deemed unworthy of 'genuine' Roman religion and attributed its origin to the inferior and syncretistic nature-worship of the 'Syrians'. ${ }^{21}$ Farnell's dismissal of the Apollo-sun identification bears witness to a clear influence of Müller. ${ }^{22}$ Other influential scholars acknowledged their acceptance of Müller's arguments, ${ }^{23}$ allowing for a recognition and reconstruction of a clearly ideological position, one highly unfavourable to the Apollo-sun identification because it was understood as a prominent example of what was believed to be lowly 'nature-worship'. This position originated in the early $19^{\text {th }}$ century and gained in strength until its culmination with Farnell, serving as a background of the dominant paradigm ever since.

Nevertheless, even though this interpretative approach appears ideologically loaded, this does not automatically mean it is wrong in its conclusions. It

\footnotetext{
${ }^{18}$ Konaris 2010, 498; 2016, 222, 237, cf. 227, 292.

${ }^{19}$ Farnell 1907, 144. Cf. Konaris 2010, 498; 2016, 228, 230, 233. For Farnell's additional chauvinistic motivation in proving the superiority of British over German scholarship see Konaris 2010, 496; 2016, 49-50, $121,202,212-214$

${ }^{20}$ Konaris 2011, 16-17; 2016, 144-149. See especially the language in Konaris 2016, 140, 146, where Müller proposes "a far more uplifting and greater" interpretation than the solar one. On Müller's predecessors and contemporary allies in the debate on the 'solar nature' of Apollo, especially J.H. Voss, who shared much of Müller's ideological (anti-Oriental) outlook, see Konaris 2016, 41-43.

${ }^{21}$ Hijmans 2009, 7, 13-14, 16, 559-560. Bernal 1987 is a controversial study of the strong anti-Oriental bias of a number of $19^{\text {th }}$-century classical scholars, which has been severely criticised, but has recently been partly vindicated by Arvidsson 2006, 11, 30, 50-51 and Konaris 2016, 20-21, 70, 136-137, 174-175.

${ }^{22}$ Konaris 2011, 19 n. 49; 2016, 223, 233. Farnell was a student of Curtius (Konaris 2010, 495; 2016, 209, 211, 213), in his turn a student of Müller (Konaris 2011, 18; 2016, 133, 162). Curtius' portrayal of Apollo is greatly indebted to his teachers' (Konaris 2016, 177).

${ }^{23}$ Von Wilamowitz-Moellendorff 1908, 28-29, whose portrayal of Apollo is reminiscent of that of his teacher Curtius (Konaris 2011, 19 n. 49; 2016, 177-178), while his opinion on the subject of the Apollo-sun identification is framed by his idea of the divine and what it entails and does not entail (Konaris 2016, 289-290 with n. 9); Fontenrose 1978, xiv (“One hundred and fifty years ago Karl Otfried Müller showed that Apollo was not the Greek sun god”); Burkert 1975, 8, cf. Konaris 2016, 294.
} 
does mean, however, that a less biased (as much as possible) reassessment of evidence is in order. ${ }^{24}$ This reassessment would be in line with Farnell's professed intention, which unfortunately in his case was followed by explaining away a not inconsiderable body of evidence for the Apollo-sun identification. Now that solar or nature-mythology is no longer considered a 'threat' - and there is also no more chauvinistic bias towards the 'Orientals'one can attempt to assess the data on their own terms. Such an attempt will be made here by bringing into sharper focus the early references to the god's involvement in the solar domain, and in this way formulating a cautious hypothesis on the nature and date of Apollo's early solar connections.

\section{Tradition vs. Interpretation: Philosophical Exegesis of Religion as the Origin of 'Solar' Apollo}

The evidence suggests that a certain belief in the connection of Apollo with the sun persisted and was current in Greek literature from at least the late sixth century onwards. In an attempt to remove the Apollo-sun identification from the domain of traditional Greek religion, but also to acknowledge its undeniable existence, the proponents of the dominant paradigm introduced a hypothesis of a 'philosophical' interpretation of traditional religion as the decisive element in the introduction of solar elements in Greek Apollo worship. ${ }^{25}$ Since this assumption was of utmost importance in relegating the Apollo-sun identification to a later, less original and less worthy stratum of Greek thought, the evidence used to support it deserves a detailed study. The hypothesis largely depends upon the perceived nature of the 'philosophical' interpretation, which is frequently attributed to the Orphics, Pythagoreans or some amalgam of the two. ${ }^{26}$ Most often it is understood as a rationalization or allegoresis (sometimes considered as its subcategory) of traditional stories

\footnotetext{
${ }^{24}$ Thus, in a way, answering the plea in Konaris 2016, 231.

${ }^{25}$ To the best of my knowledge, the interpretation of the Apollo-sun identification as 'philosophical' or 'esoteric' in origin was for the first time strongly postulated by Müller 1824, 288-289 (cf. Konaris 2011, 16; 2016, 142) and was further endorsed by Farnell 1907, 137-138.

${ }^{26}$ It is impossible to discuss the Orphic question here; I will conveniently use the terms 'Orphic' and/or 'OrphicPythagorean' in the meaning accepted by the majority of scholars. In the light of Edmonds 2013, it seems that if some Pythagorean author, or some philosopher of nature and/or an allegorist, attempted to identify Apollo with the physical sun, he might have used the medium of Orphica to do so, but his 'primary' affiliation would remain of foremost interest to further study (cf. Edmonds 2013, 163, 171-172 for such practice).
} 
about gods and their behaviour. ${ }^{27}$ But both these approaches seem somewhat problematic in this context, not the least because the ancient evidence is multifaceted, often hard to evaluate, and sometimes even outrightly contradictory.

This is precisely the case with the evidence of Pythagoras' and/or the Pythagoreans' approach to Apollo's solar identity. A rather early testimony for their attitude towards the deity is the former's identification with Hyperborean Apollo by his disciples or the Crotoniates. ${ }^{28}$ This seems both in line with the traditional Greek attitude to the divine (the presence of a deity among mortals or the deification of a deserving mortal), but at the same time differs from it in that it involves an identification of a mortal from a historical period with an epiclesis of an Olympian deity by his contemporaries during his lifetime or shortly after. In addition, no hint at either rationalization (it is not as if Apollo Hyperboreus was interpreted as a mortal deified in ancient times) or allegoresis is apparent here. Finally, it seems that no solar characteristics are attached to this Pythagorean Apollo. On a more general level, the Pythagoreans are often regarded by modern scholars as originators of allegoresisincluding physical allegoresis — of Homeric poems. The interpretation of Homeric Apollo as the physical sun would suit this particular hermeneutic strategy, but it remains unattested for the Pythagoreans, as opposed to Theagenes and other, later authors (I will address this particular line of interpretation in some detail in the following section).

Actual interpretations of traditional religion and myth that can be subsumed under the category rationalization or allegoresis attributed to the Pythagoreans by reliable sources are rather scarce. They include the Pythagorean identification of the Ursae constellations with the hands of Rhea, the planets with dogs of Persephone, the sea with a tear of Cronus, the Pleiades with the lyre of the Muses, as well as their name for the (northern celestial) pole, the seal of Rhea. ${ }^{29}$ This information can be interpreted as Pythagorean rationalization of traditional myth, ${ }^{30}$ i.e. as interpretation of certain divine persons or their attributes in terms of celestial bodies or features (in four cases) on one

\footnotetext{
${ }^{27}$ The precise type of allegoresis relevant to this context is physical allegoresis, i.e. the interpretation of traditions on gods in terms of natural phenomena.

${ }^{28}$ Arist. De Pythag. fr. 1B Ross = fr. 173 Gigon; De Pythag. fr. 1D Ross; De Pythag. fr. 2 Ross = fr. 156 Gigon. This particular tradition is clearly related to the group of stories focusing on the shadowy Aristeas and could date from as early as the first half of the $5^{\text {th }}$ century, see Burkert 1972, 149. For Pythagoras' and the Pythagoreans' involvement with Croton see Zhmud 2012, 92-102.

${ }^{29}$ Arist. De Pythag. fr. 6 Ross = fr. 159 Gigon = 58C2 DK, fr. 179 Gigon; Burkert 1972, 171; Riedweg $2005,74$. The identification of the sun and moon with the isles of the blessed (Iamb. VP $82=58 \mathrm{C} 4 \mathrm{DK}$ ) perhaps also comes from Aristotle, see Zhmud 2012, 170, 197.

${ }^{30}$ Bremmer 1999, 75; Riedweg 2005, 74-75.
} 
hand, or elements or terrestrial features (in a single case) on the other. But it does not seem that the Pythagorean tradition interpreted myth in terms of natural phenomena-it actually offered a mythologisation of these phenomena, even though the difference is rather subtle. ${ }^{31}$ In any case, the context of these identifications is vague and it remains unclear in what way they should be understood, other than that they show a clear interest in celestial matters in combination with traditional religion. ${ }^{32}$

Another example of similar practice is once again found in Aristotle's writings. He maintained that one of the Pythagoreans' explanations of the origin of the Milky Way was that it represents the path of one of the stars that fell from heaven at the time of Phaethon's fall. ${ }^{33}$ Here, once again a celestial phenomenon is explained in terms of traditional myth, which is an aition for its creation. At the same time, a comparable explanation was offered by Oenopides, who perhaps stood in some relation to the Pythagoreans. ${ }^{34} \mathrm{He}$ is reported to have suggested the meal of Thyestes as the reason for the change of the course of the sun from the Milky Way to its standard path. ${ }^{35}$ This is another example of introducing a mythic aition for current celestial phenomena (the Galaxy and the movement of the sun along the ecliptic), rather than of rationalization of myth. ${ }^{36}$ Since it seems to explain a subject that apparently interested the Pythagoreans, i.e. celestial phenomena, in terms similar to their explanations, it stands in close relation to this hermeneutical procedure, irrelevant of Oenopides' precise relation to the Pythagoreans.

My last example might be of a different nature, possibly suggesting the presence of 'physical' explanation of traditional religious beliefs in a Pythagorean setting. Later sourcesin the first place, Numenius - attribute to Pythagoras the belief that the Milky Way is Hades (or its upper limit) and the abode of

\footnotetext{
${ }^{31}$ Aristotle actually claimed that Pythagoras referred to natural phenomena in terms of mythic features, i.e. as an answer to the question 'What are the Bears' he offered an answer 'the hands of Rhea'; he did not try to explain what the hands of Rhea 'actually' were (i.e. the Bears), thus interpreting a mythic feature as a physical allegory. ${ }^{32}$ Zhmud 2012, 199, 330 questioned the authenticity of these cosmological maxims.

${ }^{33}$ Arist. Mete. 345a14-18 = 41A10 DK; cf. Alex. Aphr. In Mete., p. 37.8-22 Hayduck; Olymp. In Mete., 66.2967.32, 69.35-70.6 Stüve; Phlp. In Mete., 101.24-102.36 Hayduck; Aët. 3.1.2 = 58B37c DK; see Burkert 1972, 321-322; Kidd 1988, 487-488; Mansfeld and Runia 2010, 482-489.

${ }^{34}$ On his connections with the Pythagoreans see Zhmud 2012, 333-334.

${ }^{35}$ Oenopides 41A10 DK; Burkert 1972, 306 with n. 38, 314 n. 79, 322.

${ }^{36}$ It seems far more likely that Oenopides, as a philosopher of nature, was attempting to explain the origin of the Milky Way than to offer an interpretation of a mythic episode.
} 
the souls. ${ }^{37}$ Although this doctrine is only traceable back to heavily Platonized Neopythagorean sources, a relatively early account treating the Galaxy as the afterlife abode of souls is found in the work of Heraclides Ponticus. Here Empedotimus, an imaginary character, called the Milky Way the path of the souls who traverse the celestial Hades. ${ }^{38}$ In his vision Empedotimus further saw three eschatological gates and roads. ${ }^{39}$ This account has some share with Pythagorean tradition, but it is unclear how far the affinity goes. ${ }^{40}$ It is possible that this interpretation (or some variant of it) of mythic and eschatological features in terms of physics - or a celestial feature in terms of myth and eschatology - passed from a preHeraclidean Pythagorean source to both Heraclides and Numenius independently. Alternatively, Numenius' source could have been Heraclides, whether he himself used some earlier Pythagorean source or concocted the story in some other way. Offering mythic aitia for celestial phenomena - rather than offering rationalistic interpretations of myth — was, as we have seen, a characteristic of Pythagorean approach to both myth and natural phenomena, as was their interest in merging celestial matters with traditional religion. But the sources available at present do not allow an unequivocal acceptance of either Numenian or Heraclidean testimonies as Pythagorean in origin.

Thus the Pythagorean approach to allegoresis, as far as it is reconstructible from early and reliable sources, does not support a plausible attribution of the Apollo-sun identification to either the master or his successors. As far as Pythagoras' association with Apollo goes, there is no tangible evidence for the god's solar association in surviving accounts. In terms of either rationalization of myth or its interpretation through physical allegoresis, equally little support for the Pythagorean origin or use of these two hermeneutic strategies exists. Aristotle's list of interpretations of some (almost exclusively) celestial features in terms of myth, as well as mythic explanations of the origin of the Milky Way, seem to represent a mythologization of natural phenomena, rather than the rationalization of myth. However, it seems possible that the

\footnotetext{
${ }^{37}$ Numen. fr. 34 Des Places = Macr. Somn. Scip. 1.12.3; fr. 35 Des Places = Procl. in R. 2.129.24-26; Porph. Antr. 28.5-7.

${ }^{38}$ Heraclid. fr. 96 Wehrli = fr. 52 Schütrumpf ap. Dam. ap. Phlp. in Mete., 117.9-12, 31-32 Hayduck, with Damascius' and Philoponus' commentary in 117.12-19, 118.20-22 and 117.32-36, 118.18-23 Hayduck, respectively; cf. Gottschalk 1980, 100-101, 104, 150-154; Kupreeva 2009, 108-114. For Heraclides' opinion on the souls in the Milky Way see also fr. 97 Wehrli (= fr. 50 Schütrumpf).

${ }^{39}$ Fr. 94 Wehrli = fr. 57 Schütrumpf ap. Var. fr. 560 Bücheler; Kupreeva 2009, 103-108. On these three gates see Gottschalk 1980, 98-100, 150-151 and Reiche 1993, 168-177.

${ }^{40}$ Burkert 1972, 366-368; Kupreeva 2009, 106-108.
} 
eschatological explanation of the Milky Way actually arose from an attempt to interpret traditional mythic or religious features, such as Hades as the afterlife abode of humans, in 'physical' terms. This could well be the strongest proof for a Pythagorean physical allegoresis of traditional myth; however, this inference must be nuanced, in the first place, with the fact that it remains unclear how far we can go in attributing any part of this interpretation to either Pythagoras or early Pythagoreans. In addition, since here once again it is the Milky Way that is explained in terms of traditional religion, we might be witnessing another example of a mythologization of natural phenomena. In any case, Apollo identified with the physical sun-interpreted in terms of characteristics and behaviour of this celestial body - does not belong to this particular exegesis.

The Müllerian-Farnellian hypothesis, irrespective of its ideological background, is thus left on a rather unstable ground. But it does point the way to a palpable differentiation between a traditional and an interpretative Apollo-sun assimilation. Against this background, it is necessary to assess the nature of the evidence the early examples of identification present us with, as well as their dates, possible sources and especially the contexts in which these identifications appeared, in order to classify them into an appropriate category.

\section{Early Identifications of Apollo with the Sun: Philosophical Interpretation}

One of the earliest examples of the Apollo-sun identification is found in Aeschylus' plays. It is implied in A. Th. 856-860 and Supp. 212-214. In the former, the tragedian describes the land of the dead as a place on the other bank of the Acheron, where Apollo does not walk;

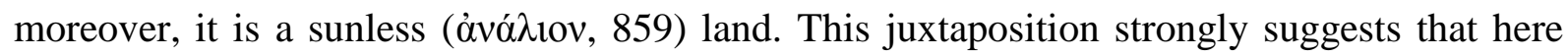
Aeschylus has in mind some close connection, if not identity, of Apollo with the sun. In the latter, Danaus and the Chorus consecutively invoke the saving beams of Helios and pure Apollo, implying the resemblance, rather than equation of the two. ${ }^{41}$ But an unequivocal identification of Apollo and Helios appears in Aeschylus' Bassarai, where it is attributed to an Orphic context, i.e. presented in a story involving Orpheus and his religious and ritual preferences. ${ }^{42}$ West and Seaford

\footnotetext{
${ }^{41}$ Diggle 1970, 147 believes the identification here as "almost certain", while Gantz 1993, 87 is skeptical.

${ }^{42} \operatorname{Tr} G F 3.138$ Radt ap. [Eratosth.] Cat. 24, cf. $\Sigma$ Germ. Arat. 273, 84.6-12 Breysig = PEGr 1148 T I Bernabé; Linforth 1941, 9-10, 205; West 1983b, 67-68; 1990, 38-39; Gantz 1993, 31, 87, 722; Seaford 2005, 602.
} 
persuasively argue that everything in Catasterismoi 24 (our source for the plot of the play) pertaining to this identification derives from the Bassarai (pace Linforth; Gantz remains sceptical): Orpheus considered Helios, whom he identified with Apollo, as the greatest of the gods after his descent to Hades. It is noticeable that here Helios is envisaged as a god venerated by Orpheus, but also as the physical sun worshipped at sunrise from a mountaintop.

What is the precise source of Aeschylus' report? West associated the information in the Bassarai with the description of Orpheus' katabasis in Plu. De sera num. vind. 22 (= Mor. 566B-C, PEGr 412 F, 998 T I Bernabé) involving Apollo, and concluded that Aeschylus and Plutarch might have used the same source, the Orphic poem Krater attributed to the early Pythagorean Zopyrus or, alternatively, an early Orphic-Pythagorean Katabasis. ${ }^{43}$ This would push back the earliest attestation of the Apollo-sun identification to a pre-Aeschylean period, although, if the attribution of the material to Zopyrus' Krater is right—and if the poem can be attributed to Zopyrus in the first place - it cannot have been the source for the Bassarai, since Zopyrus is dated to the last quarter of the $5^{\text {th }}$ century. ${ }^{44}$ We are left with a postulated preAeschylean Orphic-Pythagorean Katabasis as a plausible source for Aeschylus' account; this work was attributed to various shadowy figures, most often to one Cercops the Pythagorean. ${ }^{45}$ This author can be vaguely dated to the $6^{\text {th }}$ or $5^{\text {th }}$ century ${ }^{46}$ and would be pre-Aeschylean if his poem was the source for the Bassarai. These considerations reveal the uncertainties in determining the precise source for Aeschylus' report in the Bassarai. With all the available evidence taken into account, we might be allowed to tentatively conclude that the identification of Apollo with the physical sun apparently appeared in a work attributed to an early

\footnotetext{
${ }^{43}$ West 1983a, 11-13; 1983b, 68-69; 1990, 40-41; cf. Seaford 2005, 602.

${ }^{44}$ Kingsley 1995, 149-155; Huffman 2005, 15; Zhmud 2012, 129-130; Edmonds 2015, 273. On Zopyrus as the author of Krater see Kingsley 1995, 143-148. A Zopyrus of Heraclea is mentioned as a contemporary of Onomacritus in an unreliable tradition (PEGr 1106 T IV-VI Bernabé; West 1983a, 249-251), which perhaps led West and Seaford astray in proposing Zopyrus as the source for Aeschylus.

${ }^{45}$ Linforth 1941, 118-119, 168; Burkert 1972, 130 with n. 60; West 1983a, 9, 12; 1983b, 68; Cingano 2009, 123 125; Edmonds 2015, 268-272. Alternatively, the authorship is attributed to Prodicus of Samos or Herodicus of Perinthus; scholars have identified these figures with either Prodicus of Ceos, Prodicus of Phocaea, the professed author of the epic poem Minyas, or Herodicus of Selymbria, either a teacher of pupil of Hippocrates (Burkert 1972, 130 n. 57; West 1983a, 10 n. 17; Edmonds 2013, 189; 2015, 270-272; Tsagalis 2017, 310-311). Of the proposed authors, only Prodicus of Phocaea would predate Aeschylus (Tsagalis 2017, 316).

${ }^{46}$ Edmonds 2015, 269. For Cercops as Hesiod's contemporary, and therefore hardly a Pythagorean, see Arist. fr. 21.1 Gigon, cf. Zhmud 2012, 117.
} 
Pythagorean, presented in the medium of Orphica; this conclusion is at least not contradicted by any of the evidence at our disposal. In the light of the discussion of early Pythagorean use of traditional myth and religion presented above, neither rationalization nor allegoresis seem to explain its presence. In this context, it is perhaps more likely to see in it an attempt at mythologization, i.e. an interpretation of the sun in terms of Apollo.

There is a somewhat later testimony to an Orphic-Pythagorean assimilation of Apollo to the sun. Philochorus (ca. 340-261) wrote how men of his (or earlier) time understood Apollo as the sun, in the context of his identification of Helios and $\mathrm{Ge}$ as the parents of the Tritopatores, the universal progenitors of mankind. ${ }^{47}$ It is possible that this information comes from the second half of the $5^{\text {th }}$-century, from Orphic Physika, ${ }^{48}$ which would confirm the Orphic-Pythagorean identification of Apollo with the sun in the $5^{\text {th }}$ century. ${ }^{49}$ At the same time, this example shows another possible influence of the physical interpretation of traditional beliefs, once more (tentatively) associated with the Pythagoreans. ${ }^{50}$ But the notion of Tritopatores as progenitors in an Atthidographer is perhaps more plausibly connected to the Athenians' ancestry, even though these two concepts need not be understood as contradictory. Indeed the fragment can be read so as to mean that Helios (i.e. Apollo) and Ge were the original parents of mankind, as well as of the Tritopatores, ${ }^{51}$ or as referring to the ancestry of the Athenians, not mankind in general. ${ }^{52}$ The notion of Helios and Ge as ancestral deities indeed appears in the Athenian tradition beyond Philochorus, although only in late sources. These sources explain the claim to autochthony of the Athenians through their progenitors Earth and Sun, the latter being identical to (their ancestral) Apollo. ${ }^{53} \mathrm{We}$ shall see that this Apollo Patroios was invoked in Athenian oaths, perhaps as the sun; his role as ancestor of the Athenians is closely connected to the sun's ancestry of mankind in general in Philochorus, which is attested much earlier than the sun's ancestry of the Athenians. In fact, if the account in Philochorus truly comes

\footnotetext{
${ }^{47} B N J$ 328F182. For this usual understanding of the fragment see Gagné 2007, 14-16. For the date of Philochorus see Jones in BNJ 328 Biographical Essay.

${ }^{48}$ Gagné 2007, 14-15 with n. 48.

${ }^{49}$ For the date of the Physika see Gagné 2007, 7, 12-13, 19 (cf. PEGr fr. 802i Bernabé). The work was ascribed to Alcmaeon's contemporary Bro(n)tinus, who must have lived ca. 500: Burkert 1972, 114, 289 n. 57; West 1983a, 9, 11, 13; Zhmud 2012, 120, 122; Gagné 2007, 8-9, 13.

${ }^{50}$ Gagné 2007, 6, 8-9, 12-13, 16, 19.

${ }^{51}$ Robertson 2010, 175-176.

${ }^{52}$ Simon 1983, 76. On the misleading dichotomy of local vs. universal origin of humanity see Loraux 2000, 10$11,85,87$.

${ }^{53}$ Byzantine-period Lexicon of Rhetorical Terms in Anecd. Grae. 291.33-292.3 Bekker; $\Sigma$ Pl. Euthd. 302c, 2.369 Bekker; $\Sigma$ D Aristid. 97.16, 3.28 Dindorf.
} 
from an Orphic Physika, it could well be an Orphic-Pythagorean interpretation of the traditional Apolline ancestry of the Athenians, which occasionally penetrated into some more mainstream sources.

Another early testimony for the identification of Apollo with the sun in a philosophical context is found in Parmenides 28A20 DK, accompanied by Empedocles 31A23 DK = R96 Laks and Most. Menander Rhetor $\left(3^{\text {rd }} / 4^{\text {th }}\right.$ century AD) wrote in his Peri epideiktikôn how Parmenides and Empedocles composed hymns about nature. ${ }^{54}$ These hymns sometimes identified Apollo with the sun, and both Parmenides and Empedocles were masters of the genre; moreover, according to Menander, they gave 'full expositions' of the concept. ${ }^{55}$ For his part, Empedocles indeed wrote a hymn to Apollo, ${ }^{56}$ which is perhaps partially preserved at Ammon. In Int. ${ }^{57}$ Although Empedocles speaks in the fragment about the divine in general, at the same time his immediate subject is Apollo, if we are to believe Ammonius (there seems to be no reason why we should not believe him). ${ }^{58}$ Even though this fragment in no way identifies Apollo with the sun, the god must have been brought into connection with the celestial body in Empedocles' hymn. ${ }^{59}$ Although we have more evidence on Empedocles on this subject, the earlier date of Parmenides - the problems with his date caused by differing accounts in ancient sources notwithstanding-gives him chronological precedence in this context. $^{60}$ Menander is categorical in attributing to these two philosophers an explicit identification of deities with physical entities, including that of Apollo with the sun. Unfortunately, he does not distinguish between the two, and nowhere in the ample remains of Parmenides' writings - as opposed to Empedocles'-do we find any hint at the Apollo-sun identification. Still, Menander must have had some reason in attributing it to the earlier philosopher, even if his precise motives eludes us.

One more early testimony, Theagenes of Rhegium's (ca. 525 BC), can be associated with the tradition exemplified in the preceding paragraph. Instead of his traditional label 'the originator of physical allegoresis', Theagenes is understood by recent scholars as a representative of physical allegory, which implies

\footnotetext{
${ }^{54}$ 1.2.2, iii.333 Spengler; Russell and Wilson 1981, 6-7.

55 1.5.2, iii.337 Spengler = 28A20, 31A23 DK; Russell and Wilson 1981, 14-15. Cf. Gantz 1993, 87. Such hymns were also composed by Orpheus (Men. Rh. 1.2.2 = PEGr 683T I Bernabé) and the Pythagoreans (Men. Rh. 1.5.2).

${ }^{56}$ Arist. fr. 17 Gigon, Hieron. fr. 30 Wehrli $=31 \mathrm{~A} 1 \mathrm{DK}=\mathrm{P} 25 \mathrm{a}$ Laks \& Most.

${ }^{57}$ CIAG iv.5, p. 249.1-11 Busse = 31B134 DK = R95 Laks and Most with D93.

${ }^{58}$ Solmsen 1980, 220-221, 223-224; Kingsley 1996, 111; Inwood 2001, 68.

${ }^{59}$ Solmsen 1980, 221, 224.

${ }^{60}$ On the questions of Parmenidean chronology see Kirk, Raven and Schofield 1983, 240; Mansfeld 1990, 64-68, 82 n. 221; Coxon 2009, 39-40.
} 
that this type of Homeric interpretation existed at least somewhat earlier, tentatively originating in a Pythagorean context, perhaps the actual source of Theagenes' hermeneutics. ${ }^{61}$ The claim for him being an early author who identified Apollo with the sun rests on a scholion to the Iliad attributed to Porphyry (8A2 DK). The text of the scholion leaves it uncertain whether it was actually Theagenes who identified Homer's Apollo, Helios, and Hephaestus with 'fire'. If it was indeed the early allegorists, ${ }^{62}$ it seems certain that he considered Apollo and Helios alike in nature, which is important, because while it is only natural to associate Helios and Hephaestus with fire, it is not so easy to associate Apollo with this element, unless we presuppose his solar character. This is further strengthened by the Artemis-Selene identification found in the same text. Two more or less plausible inferences have to be accepted in order for this testimony to be recognised as a genuine early attestation of the Apollo-sun identification: (1.) the paraphrase in the scholion stems from Theagenes himself (i.e. not only the last sentence in which he is styled the earliest physical allegorist) and (2.) whoever is the author of these tenets actually identified Apollo with the sun, rather than only with fire. Both inferences seem plausible enough, but certainty is impossible. Moreover, a Pythagorean background - however tentative-for the whole concept of physical allegory has been postulated in the context of Theagenes' contribution, which corresponds to what I have argued for the sources of Aeschylus' account in the Bassarai, and perhaps also to Parmenides' and Empedocles' identifications.

Several other authors, none later than the first half of the $4^{\text {th }}$ century, assimilated Apollo to the sun in what could be called a philosophical context. Oenopides of Chios $\left(2^{\text {nd }}\right.$ half of the $5^{\text {th }}$ century) explained Apollo's epithet Loxias with the sun's traversing the oblique

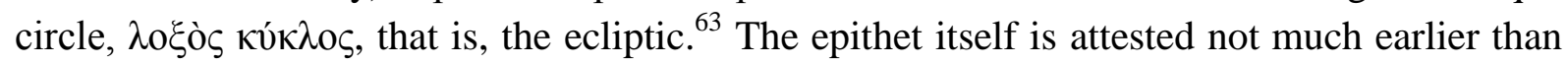
Oenopides himself, ${ }^{64}$ while the notion of the obliquity of the sun's path can hardly be ascribed to an early period of Greek cosmological speculation. Therefore we would have to assume an anachronistic motivation for the coining of the epithet. But Oenopides' motivation for offering this particular interpretation of the epithet is missing if Apollo was not considered identical to the sun

\footnotetext{
${ }^{61}$ Lamberton 1986, 15, 31-33, 38, 43, 322, citing earlier scholarship on the subject; 1997, 43; Ford 1999, 37. For the discussion of Theagenes' role in the introduction of allegoresis in Homeric exegesis see Ford 1999, 35-38, 45-46, contra Domaradzki 2011, 205-227.

${ }^{62}$ Naddaf 2009, 125 n. 37; Domaradzki 2011, 211, 217.

${ }^{63} 41 \mathrm{~A} 7 \mathrm{DK}$, by way of Apollod. FGrHist 244F95.

${ }^{64}$ First in Pindar (P. 3.28, 11.5, I. 7.49, Pae. 6.60, Parth. 2.3), Aeschylus (Eu. 19, 35, 61, 235, 241, 465, 758, Pr. 669, Th. 618, A. 1074, 1208, 1211, Ch. 269, 558, 900, 953, 1030, 1036, 1039, 1059, TrGF fr. 86 Radt) and Bacchylides (31(iii).86, 40(xii).148).
} 
before his time, or at least if this interpretation of Apollo's character would not have been regarded as completely unfamiliar. Once again, the identification provided by Oenopides was considered to have a Pythagorean flavour, mainly on account of his interest in astronomy and mathematics. ${ }^{65}$

A philosophical frame of reference was postulated for two more $5^{\text {th }}$-century authors, a famous tragedian and a iambic poet, interested in the interaction of Apollo with the sun. ${ }^{66}$ Euripides spoke of Apollo as a mortal's name for Hêli(os); but the name is rightly given to him only by those who know the concealed names of gods. ${ }^{67}$ This certainly does not mean that the sun was regularly called Apollo, at least as far as Euripides was concerned, although it is also no consecutive proof that the notion was not widespread. ${ }^{68}$ Certainly Euripides here referred to the current etymology Apollo $=$ Destroyer, ${ }^{69}$ using the aorist of $\alpha \dot{\alpha} \delta \lambda \lambda v \mu$ in describing Helios' action against Phaethon (and, indirectly, Clymene), in the context of his Apollo-Helios identification. ${ }^{70}$ At the same time, a potential allusion to mystic-i.e. Orphic/Pythagorean - initiation has been recognized in the notion of the knowledge of 'silent names' of the gods, ${ }^{71}$ which would add this testimony to the evidence for an Apollo-sun identification in the early Pythagorean exegesis of traditional religion and mythology.

Another Apollo-sun identification with philosophical resonances is found in the work of the iambic poet Scythinus, dated to the $5^{\text {th }}$ or $4^{\text {th }}$ century. ${ }^{72}$ He apparently composed a poem in which he expounded Heraclitus' philosophy in verse. ${ }^{73}$ In one of the few preserved fragments of this work he described the rays of the sun as the plectrum of Apollo's lyre. ${ }^{74}$ This Apollo is clearly cosmic in character, joining together or comprehending beginnings and ends; the lyre

\footnotetext{
${ }^{65}$ Boyancé, cited by Seaford 2005, 606 n. 27.

${ }^{66}$ Farnell 1907, 137.

${ }^{67}$ E. Phaëth. 224-226 Diggle. Gantz 1993, 34 tentatively recognized Apollo mounted upon a horse in the scene of Phaethon's death on an Arretine bowl (LIMC 7.1.353, 2.313 s.v. Phaethon I 24), thus possibly reflecting Euripides' account (cf. Gantz 1993, 32 on E. Phaëth. 175-176 Diggle).

${ }^{68}$ Fontenrose 1940, 441; Seaford 2005, 604.

${ }^{69}$ Cf. A. Ag. 1080-1082 with Hunter and Laemmle 2020, 388-389; Archil. fr. 26.5-6 West; Pl. Cra. 404de, 405e; see also Hippon. fr. 25.1 West.

${ }^{70}$ Diggle 1970, 148.

${ }^{71}$ Seaford 2005, 604.

72 Bowie, 'Scythinus', in BNP; Rotstein 2010, 49; Fowler 2013, 732. West 1974, 33, 177 and Gerber 1999,10 date him to the $5^{\text {th }}$ century, while Kirk 1962,11 dates him to the late $4^{\text {th }} /$ first half of the $3^{\text {rd }}$ century.

${ }^{73}$ Hieron. fr. 46 Wehrli.

${ }^{74}$ Fr. 1 West.
} 
itself can thus be understood as cosmic. ${ }^{75}$ Here Apollo is closely associated with the sun, even though the two are not explicitly identified. Since Cleanthes similarly interpreted 'plectrum' as the sun(ray), ${ }^{76}$ and at the same time identified Apollo with the sun, ${ }^{77}$ Kirk's argument for a later date for Scythinus and his contextualization of his work in a Stoic setting seems persuasive. ${ }^{78}$ On the other hand, West equally persuasively argues for Scythinus' earlier date and convincingly contextualizes the fragment in a Presocratic setting, which does not exclude the author from the group of early authors who identified Apollo with the sun.

Finally, although Farnell included Timotheus of Miletus' Apollo-sun identification among the testimonies that exhibit speculative tendencies of their authors, ${ }^{79}$ none of these are apparent in his work that belongs to the second half of the $5^{\text {th }}$ or the first half of the $4^{\text {th }}$ century. ${ }^{80}$ Timotheus (800 PMG) seems to have given a solar 'interpretation' of Apollo's

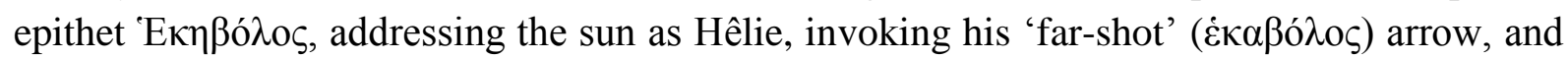
further addressing him as Paean, thus almost certainly equating him with Apollo. ${ }^{81}$ It seems that this identification can be interpreted as an understanding of certain features of traditional religion and myth (i.e. two of Apollo's epithets, Hekêbolos and Paian) in terms of physical phenomena, but not necessarily under the influence of natural philosophy, although the latter cannot be categorically discarded.

\section{Early Identifications of Apollo with the Sun: The Evidence from Tradition (Myth and Cult)}

In contrast to the testimonies analysed so far, there is a considerable body of evidence for the Apollo-sun interaction that cannot be subsumed under the category of 'philosophical interpretation'. Apparently one of the earliest authors assimilating Apollo to the sun was the Argive poetess Telesilla, who lived in the first half of the $5^{\text {th }}$ century, perhaps even in the late $6^{\text {th }}$ century. ${ }^{82}$ She

\footnotetext{
${ }^{75}$ Cf. Burkert 1972, 320 n. 107, following Boyancé, who understood the lyre as the homonymous constellation.

${ }^{76}$ Fr. 502 SVF.

${ }^{77}$ Frs. 540-542 SVF.

${ }^{78}$ Cf. n. 72 above.

${ }^{79}$ Farnell 1907, 137.

${ }^{80}$ Robbins, 'Timotheus 2', in $B N P$.

${ }^{81}$ Cf. Hunter 1986, 59; Ford 2006, 288; Hunter and Laemmle 2020, 383 n. 19.

${ }^{82}$ Robbins, 'Telesilla' in BNP; Plant 2004, 33.
} 


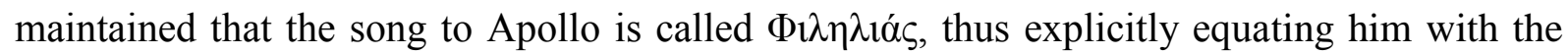
physical sun. ${ }^{83}$ This testimony is explained away by Farnell, on account of the fact that Pollux 9.123 does not mention Apollo in his discussion of this type of song, as opposed to Athenaeus $14.619 \mathrm{~b}$, who transmits the fragment. ${ }^{84}$ Rather than relying on this feeble argument, one could perhaps claim that it is only Athenaeus who assumed that the songs called $\Phi i \lambda \eta \lambda$ iós are addressed to Apollo, rather than Telesilla herself. But even if we bear in mind that only the word $\Phi ı \lambda \eta \lambda ı$ '́s is actually Telesilla's, ${ }^{85}$ Athenaeus never equated the two deities in his work and it seems unconvincing that he would do so solely in this place if the immediate context does not suggest it. The context — in itself apparently cultic (parodied both by Pollux and Strattis fr. 46 Kassel-Austin whom Pollux cites) — could have been provided only by Telesilla herself, and it seems more likely that she is the author of this particular Apollo-sun identification.

Telesilla's testimony points to a cultic context of an Apollo-sun identification, even though Strattis $\left(5^{\text {th }} / 4^{\text {th }}\right.$ century $\left.\mathrm{BC}\right)$ emphasized the comical aspect of the children's plea to the sun to come out and its obedience to their 'authority'. There are other early examples of the identification in cultic contexts, which equally point to a traditional, i.e. non-philosophical, assimilation of Apollo to the physical sun. One is the story of Euenius. ${ }^{86}$ It deals with the sacred sheep of the sun residing in a cave near the Adriatic Apollonia. There is no direct identification of the two deities here, but several pieces of information suggest that the Greeks of Herodotus' time understood the story in this way. ${ }^{87}$ The city was founded ca. $600 \mathrm{BC}$ (the traditional date is $588 \mathrm{BC}) ;^{88}$ the local tradition of the mid- $5^{\text {th }}$ century alleges that it was founded by Apollo. ${ }^{89}$ Indeed, the dominant cult in the city was that of Apollo, which the name of the city clearly suggests. ${ }^{90}$ At the same time, as a city in the far west of the Greek world, it is an appropriate place for a strong association with the sun, to which the cult of the sun's sacred sheep certainly, and the name of the city possibly, testifies. ${ }^{91}$

\footnotetext{
${ }^{83} 718 P M G$.

${ }^{84}$ Farnell 1907, 137.

${ }^{85}$ PMG p. 372; Campbell 1992, 78-79; Plant 2004, 35 n. 10.

${ }^{86}$ Hdt. 9.93-94, with a variant in Con. FGrHist 26F1.30, where he is called Pithenius.

${ }^{87}$ Cf. Griffiths 1999, 173, 175-176.

${ }^{88}$ Hansen and Nielsen 2004, 328.

${ }^{89}$ CEG 390 = Paus. 5.22.3. The monument with the inscription dates from the late 430s, Corso 2004, 49-51.

${ }^{90}$ Hansen and Nielsen 2004, 329.

${ }^{91}$ Griffiths 1999, 175; Davies 2006, 197.
} 
Another cultic element, also in the western fringe of the Greek world, might point to the Apollo-sun identification. ${ }^{92}$ The so-called Little nekuia describes how the souls of the

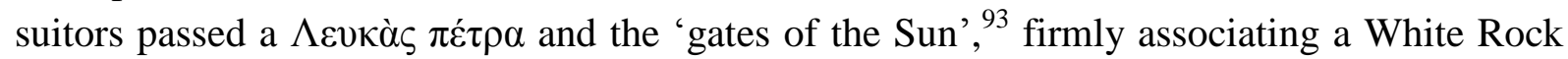
with the sun. However, in subsequent periods a homonymous toponym was equally firmly associated exclusively with Apollo. Already Anacreon $\left(2^{\text {nd }}\right.$ half of the $6^{\text {th }}$-early $5^{\text {th }}$ century) mentioned a $\Lambda \varepsilon v \kappa \alpha ̀ \varsigma ~ \pi \varepsilon ́ \tau \rho \alpha$ as a place used by those who believed they could heal their wounds inflicted by love by jumping from it. ${ }^{94}$ Perhaps an even earlier testimony to this tradition is found in the poem Calyce, if it can be attributed to Stesichorus (late $7^{\text {th }}$-first half of the $6^{\text {th }}$ century), as the Peripatetic Aristoxenus suggests. ${ }^{95}$ The author of the poem-who certainly lived earlier than Menander-knew of the attempt of unhappy lovers to cure their affliction by jumping of a precipice at Leucas, which is the earliest positive association of the Rock with the actual island. ${ }^{96}$ This Rock must be connected with the location of the temple of Apollo on the homonymous island, which is first mentioned by Thucydides. ${ }^{97}$ It was sometimes associated with the hurling of criminals at a sacrifice to Apollo or a jump during an Apolline festival, ${ }^{98}$ which emphasizes the cultic aspect of the phenomenon. It seems that the presence of Apollo at the White Rock represents a paradigmatic shift with respect to the sun's association with this locality in the Odyssey. It is possible that the author of this section of the $24^{\text {th }}$ book of the Odyssey modelled his account upon the existing cultic reality; ${ }^{99}$

\footnotetext{
${ }^{92}$ On the entire subject see Nagy 1973 and Beaulieu 2016, 147-149.

${ }^{93} \mathrm{Od}$. 24.11-12. For the relation of deuteronekuia with the rest of the poem see Russo, Fernández-Galiano and Heubeck 1992, 356-358. For the $24^{\text {th }}$ book as an integral part of the Odyssey see de Jong 2001, 561-562, 565566.

${ }^{94}$ PMG 376; cf. E. Cyc. 166; Men. fr. 258 Körte and Thierfelder. For a reconstruction of Menander's Leucadia see Arnott 1997, 220-243 with Turpilius' Leucadia frs. XI-XII Ribbeck ${ }^{3}$, Rychlewska.

${ }^{95}$ Stesich. $P M G 277$ = fr. 326 Finglass (both under spuria) ap. Aristox. fr. 89 Wehrli. For the latest assessment of the subject, with a slight inclination towards the acknowledgement of Stesichorus' authorship, see Rutherford 2015, 98-108; Davies and Finglass 2014, 601-604 are more skeptical.

${ }^{96}$ If the association of the Rock with the island of Leucas is only due to Aristoxenus, then Menander's play remains the earliest positive association of the Rock with the actual island. The latter is certainly the earliest attested association of the Rock with Apollo's temple on the island. For other $4^{\text {th }}$-century comic playwrights who wrote similarly-titled plays see Arnott 1997, 222.

${ }^{97}$ 3.94.2. Most likely not a temple in the polis itself, but the famous sanctuary at Cape Doukato, Fiedler 1996, 160; Morris 2001, 340.

${ }^{98}$ Str. 10.2.9; Ael. NA 11.8; Liber memorialis 8.4; Serv. Dan. A. 3.279; perhaps Ov. Fast. 5.630 and Phot. s.v.

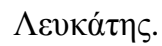

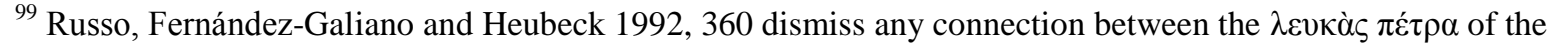

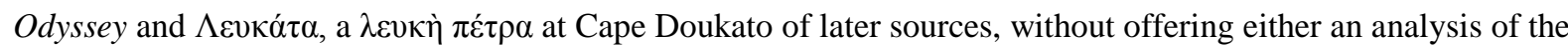
evidence or arguments for the dismissal.
} 
either way, an early and non-philosophical identification of Apollo with the sun is possibly attested here.

Apart from these cultic associations, another possible traditional identification of Apollo with the sun can be recognized in a complex of myths involving a cattle-raid and a cave at Pylos. Its recognition requires a more elaborate argumentation, but at the same time provides a clear example of a paradigmatic replacement of Helios with Apollo in early myth. In the Homeric Hymn to Hermes Apollo's cattle are driven by Hermes to a cave at Pylos. ${ }^{100}$ It is sometimes claimed that in this context Apollo's cattle have at least a distant solar undertone, ${ }^{101}$ but this inference can be sustained only on the basis of further considerations.

Parallel to this story, a number of myths place the cattle of both Neleus and Nestor in a cave at Pylos. ${ }^{102}$ With respect to the former, according to one version, Neleus and his sons had actually stolen Geryon's cattle from Heracles. ${ }^{103}$ It can be plausibly claimed that these belonged to the sun: Helios indeed had his cattle at two opposite points on the earth, both where he rises and where he sets; ${ }^{104}$ the latter could be his herds on Erytheia. ${ }^{105}$ Erytheia is often associated with the (Western) Aethiopians, ${ }^{106}$ surely with reference to sunset, ${ }^{107}$ as well as with the Hesperides. ${ }^{108}$ Furthermore, in order to obtain Geryon's cattle

\footnotetext{
${ }^{100}$ h.Merc. 18, 22, 68-86, 101-102, 191-192, 216, 221, 262, 276-277, 308-311, 340-342, 344, 355, 371, 398, 401, 503. According to $\Sigma$ D.T. 2 (174.2-3 Hilgard), Hermes actually stole the cattle of Helios, but this is probably only due to a later identification of Apollo with the sun or the scholiast's interpretation of the Hymn in the context of this later tradition. The author of the Hymn clearly distinguished Apollo from Helios: Vergados 2013, $67,288,481$. For the date of the Hymn (second half of the $6^{\text {th }}$ century) see Vergados $2013,130,145-147$ (with an extensive review of earlier opinions on 130-145).

${ }^{101}$ Croon 1952, 80; Solomon 1994, 42, 44-45.

102 Paus. 4.36.2.

${ }^{103}$ Isoc. Or. 6.19, cf. Philostr. VS 1.17; Agias FGrHist 305F1; Philostr. Her. 26.3; Croon 1952, 19; Walcot 1979, 335. This theft is perhaps represented on Euphronius' cup (LIMC 5.1.77, 5.2.89 s.v. Herakles 2501), Gantz 1993, 403, 409. For another version, according to which the cattle, owned by king Iphicles, were brought to Pylos by a seer Melampus from Phylace, see Od. 11.287-297, 15.225-238; Hes. fr. 37 MW, fr. 261 MW ap. $\Sigma$ P A.R. 1.118, p. 16 Brunck \& Schaefer; Pherecyd. BNJ 3F33 etc. No solar references can be detected in this story.

${ }^{104}$ Od. 12.379-382; Nakassis 2004, 226-227.

105 [Apollod.] 1.6.1; $\Sigma$ Pi. I. 6.47b, 3.254-255 Drachmann; Gantz 1993, 419-420.

${ }^{106}$ Ephor. BNJ 70F129b; D.P. 558-561.

${ }^{107}$ For the Western Aethiopians associated with sunset see A. $\operatorname{Tr} G F$ fr. 192 Radt; A.R. 3.1191-1194.

${ }^{108}$ Stesich. S 8 = 184A $P M G=$ fr. 10 Finglass; $\Sigma$ A.R. 4.1396-1399d, p. 317 Wendel. For a Hesperid Erytheia see Hes. fr. 360 MW; A.R. 4.1427; probably [Arist.] Mir. 133.843b28, 30-31; [Apollod.] 2.5.11. She is said to have been Geryon's daughter (Paus. 10.17.5 with St.Byz. s.v. 'E $\rho v 0 \varepsilon 1 \alpha$; cf. Hellanic. BNJ 4F110).
} 
from Erytheia Heracles had to cross the Ocean in Helios' cup. ${ }^{109}$ Erytheia thus represents a western diurnal portal of the sun, and the cattle brought from there to Pylos certainly belonged to Helios' herds. ${ }^{110}$

With respect to Nestor's cattle, they were brought to Pylos by the hero himself. He led a marauding expedition to Elis, ${ }^{111}$ which at the time was ruled by Helios' son Augeas. ${ }^{112}$ The latter's name is probably related to the word $\alpha$ ơ $ү$, 'radiance (of the sun) ${ }^{113}$ and it is possible that Augeas was originally Halieios, Helios' son, which was converted by the epic tradition into Waleîos, 'Eleian'. ${ }^{114}$ His solar associations go beyond his name and ancestry: he was the owner of the cattle among which were twelve swan-white bulls sacred to Helios, whose leader was named Phaethon; ${ }^{15}$ further, he had a daughter named Agamede, well-versed in pharmacopoeia, who, as Perimede, was linked with both Circe and Medea. ${ }^{116}$ Thus there is an obvious similarity between Medea (Circe)/Aeëtes on one hand and Agamede/Augeas on the other. ${ }^{117}$ In the light of the fact that Aeëtes' family belonged to Helios', ${ }^{118}$ these considerations support the solar interpretation of Augeas' cattle. ${ }^{119}$

In this way, the cave at Pylos is a place where stolen cattle were regularly deposited; most often these cattle can be interpreted as belonging to the sun-god. This is the case with Geryon's cattle, Augeas' cattle, as well as with Apollo's cattle from the Hymn to Hermes. Why would Pylos be such a convenient place for the sun's cattle? The name probably connotes the entrance to Hades, ${ }^{120}$ but

\footnotetext{
${ }^{109}$ Stesich. S 17 = 185 PMG = fr. 8b Finglass; Pisand. fr. 6 Davies = fr. 5 West; Panyas. fr. 7A Davies $=$ fr. 12 West, cf. Macr. Sat. 5.21.19; A. TrGF fr. 74 Radt; Pherecyd. BNJ 3F18a, cf. [Apollod.] 2.5.10, Macr. 5.21.19; Antim. fr. 66 Wyss, West, according to Allen 1993, 95.

${ }^{110} \mathrm{Cf}$. Solomon 1994, 40. At the same time Erytheia is a region under some kind of sovereignty of Hades (Croon 1952, 32; Davies 1988, 278-282; 1992, 221; 2006, 196-198, 200, 204; Fowler 2013, 304). For a similar collocation of the sun god's cattle and (an entrance) to Hades see h.Ap. 411-413 (Taenarum).

${ }^{111}$ Il. 11.671-684.

${ }^{112}$ A.R. 1.172 with $\Sigma 1.172-1173$, p. 22 Wendel, 3.362; Theoc. 25.54, 118; [Apollod.] 1.9.16, 2.5.5; Hyg. Fab.

14; Paus. 5.1 .9 etc.

${ }^{113}$ Frame 1978, 88; cf. Burkert 1979, 95; Sick, 2004, 442.

${ }^{114}$ Burkert 1979, 95.

115 Theoc. 25.129-131, 139.

${ }^{116}$ Il. 11.741, cf. Str. 8.3.5; $\Sigma$ Theoc. 2.15-16b (Perimede); Theoc. 2.14-15; cf. Prop. 2.4.7-8; Hainsworth 1993, 303.

${ }^{117}$ Wernicke 1896, 2309.41-42; Frame 1978, 88-89.

118 Aeëtes son of Helios: Od. 10.137-138; Hes. Th. 956; Eumel. fr. 17 West etc. Circe daughter of Helios: Od. 10.137-139; Hes. Th. 956-957, cf. 1011; probably Hecat. fr. 35A Fowler etc.

${ }^{119}$ Cf. Frame 1978, 90; Davies 2006, 197.

${ }^{120}$ See (on Il. 5.397) Croon 1952, 57 with n. 19; Nagy 1973, 139-140; Kirk 1974, 191; Fontenrose 1974, 329330; Frame 1978, 92-93; 2009, 537 n. 55; Burkert 1979, 86, 88-89; Dowden 1992, 98; Gantz 1993, 70; Davies 2006, 195; Fowler 2013, 304.
} 
it can also be - as a location on the western coast of Peloponnese-associated with the sunset gates of the sun. ${ }^{121}$ We have evidence for this collocation of solar and Hades associations for both Erytheia and Taenarum; therefore it can be safely posited for Pylos, as well. At Erytheia the cattle of the sun/Hades are located on the sunset island, at Taenarum the gates of Hades are collocated with the cattle of Helios, while at Pylos the gates of Hades are on this interpretation also firmly associated with solar cattle. Apollo's cattle from the Hymn to Hermes can thus be interpreted in terms of an appropriation of a traditional story primarily concerned with solar cattle, ${ }^{122}$ even though the author of the Hymn apparently did not recognize - or failed to acknowledge - this in his engagement in bricolage. However, he did consider the two gods to be similar enough in order to replace the one with the other in the context of the traditional story he appropriated. On the other hand, he could have used an existing story in which Apollo was already identified with the sun as the owner of solar cattle, which would then date the identification before the second half of the $6^{\text {th }}$ century. ${ }^{123}$ In the light of the explicit differentiation of the two gods in the Hymn, the latter hypothesis seems more likely.

These considerations strongly suggest that anonymous bricoleurs could freely replace Helios with Apollo in their renderings of traditional stories current in the $6^{\text {th }}$ century. It seems that one can hardly attribute to them specialist attempts at philosophical or physical interpretation of traditional myth and religion, to which they otherwise show little or no inclination. Their creations are firmly rooted in the realm of traditional myth, and their assimilation of Apollo to the sun should be treated as a feature of a non-philosophical understanding of Apollo.

In a similar vein, it could be argued that an early identification of Apollo with the sun appears in a specific iconographic representation known through

\footnotetext{
${ }^{121}$ Harrison 1908. 13; Croon 1952, 80; Nagy 1973, 139-140; Solomon 1994, 41.

${ }^{122}$ Solomon 1994, 42, 44-45.

${ }^{123}$ A colophon of a similar tale in Antoninus Liberalis 23.5, involving Hermes stealing Apollo's cattle and driving them to the cave at Pylos, cites as the earliest of its sources the Hesiodic Great Ehoiai (fr. $256 \mathrm{MW}$, fr. 194b Most). Even if the entire story was in the Great Ehoiai, which does not seem very likely (cf. D'Alessio 2005, 196; Most's fr. 194a is restricted to the genealogy of Magnes at the beginning of Ant.Lib. 23.1), it would not push the date of this particular identification much further back (presuming that the above considerations with respect to the identification also apply to this work), since the Hesiodic Catalogue is generally dated to a similar period, i.e. either the earlier or later part of the $6^{\text {th }}$ century (Hunter 2005, 2-3; D'Alessio 2005, 201, 205 specifically on Great Ehoiai; on the relationship of Catalogue with Great Ehoiai see Cingano 2009, 118-121 and D'Alessio 2005, 176-179, 186-188, 205, 213).
} 
only two examples on Attic vases. ${ }^{124}$ First, on a neck-amphora of the Ready Painter dated to the third quarter of the $6^{\text {th }}$ century, Apollo with a cithara is shown in a tripod traveling on the sea, indicated by two dolphins. ${ }^{125}$ Another almost identical representation is depicted on a hydria of the Berlin Painter, dated to ca. 480. Here the sea is indicated with fish and an octopus, as well as two dolphins jumping over waves; the tripod is winged, and laureate Apollo carries a bow and quiver on his back and holds a lyre and plectrum. ${ }^{126}$ This seems like an interpretation of the sun's voyage in his golden cup, known to the Greeks as early as the second half of the $7^{\text {th }}$ century, adapted to the iconography of Apollo. ${ }^{127}$ The artists who decorated these vases therefore seem to have identified Apollo with Helios; ${ }^{128}$ otherwise it is difficult to interpret the iconography (this odd way of transport is nowhere mentioned in myths of Apollo, so it can be safely attributed to Helios). ${ }^{129}$

Another example of a possible Apollo-sun identification in a non-philosophical context appears in Athenian civic documents. A triad of Zeus, Apollo and Demeter is evoked in several $5^{\text {th }}$-century public oaths, ${ }^{130}$ and during the $4^{\text {th }}$ century it appears as a standard invocation in Athenian public oaths. ${ }^{131}$ Indeed, in the Athenian judges' oath Apollo Patroios, Demeter and Zeus were invoked, but a parallel account has Helios instead of Apollo. ${ }^{132}$ Furthermore,

\footnotetext{
${ }^{124}$ The type is called Apollo huperpontios by Beazley 1956, 685 n. 8 .

${ }^{125}$ LIMC Apollon 381.

${ }^{126}$ LIMC Apollon 382.

${ }^{127}$ For Helios' winged golden couch see Mimn. fr. 12.5-10, cf. fr. 23 West; for his golden cup see Titanomach. fr. 10 West; Sapph. fr. 58 Voigt in P. Köln 21351, 1.18 (Gronewald and Daniel 2004a; 2004b); Stesich. S $17=$ $185 P M G=$ fr. 8a Finglass; Pherecyd. BNJ 3F17, cf. [Apollod.] 2.5.11, F18a, cf. [Apollod.] 2.5.10 (also from Pherecydes?; see Jacoby FGrHist Comm. 1.395, 397 (who is critical); Van der Valk 1958, 127, 129; Fowler 2013, 291, 298-299); Pisand. fr. 5 West; Panyas. fr. 12 West; A. TrGF frs. 69, 74 Radt; Antim. fr. 66 Wyss, West; Theolyt. FGrHist 478F1. For artistic representations of Helios in a boat from the late $6^{\text {th }}$ century onwards see LIMC 5 Helios 2, 99, 100, 102, Helios/Usil 30, with Krauskopf 2013, 517. For $6^{\text {th }}$ and $5^{\text {th }}$-century artistic representations of Heracles in Helios' cup see LIMC 5 Helios 101, Herakles 2550-2552.

${ }^{128}$ Pace Gantz 1993, 88, who claims that the two were never 'confused' in early art.

${ }^{129}$ Beaulieu 2016, 144 interprets this depiction as an illustration of Apollo's annual voyage from Delphi to Hyperborea; but the god actually used his swan-chariot for this voyage (Alc. fr. 307c Lobel-Page).

${ }^{130}$ Erythraean decree of 453/452 (Osborne 2000, 113-114 nos. 216AB); Colophonian decree of 450-447/446 (IG $\mathrm{I}^{3} .37 .53$; Kagan 1969, 99-100, 118); cf. Ar. Eq. 941 (424).

${ }^{131}$ SEG 33 147.A.60 (380-375, a sacrificial calendar of an Attice deme); IG II $^{2} .97 .24,36$ (375/374, treaty with Corcyra); [D.] 52.9 (369/8); Rhodes and Osborne 2003, 312-313 no. 63 (3/4 of the $4^{\text {th }}$ century decree of an Attic deme); Din. fr. 29 Conomis (who specifically invokes Apollo Patroios).

132 Poll. 8.122; Synagoge B a 2113 Cunningham, a Byzantine-period lexicon.
} 
a scholiast on Demosthenes' Against Meidias (Menander Rhetor?) claimed that in an Athenian oath sworn in the name of Apollo, Athena and Zeus, Apollo represents the sun. ${ }^{133}$ Has an Athenian Apollo-sun replaced the customary Helios in oaths ${ }^{134}$ The earliest Athenian occurrence of the Zeus-Ge-Helios triad in oaths appears in the treaty of $356 / 5$, i.e. a century later than the Zeus-Apollo-Demeter triad. ${ }^{135}$ Thus the question necessarily remains open, although once again either a 'physical' interpretation of a traditional religious tenet or a traditional Athenian understanding of the deity could serve as an explanation, on the condition that it was Helios who replaced Apollo in oaths; but neither substitution seems very convincing.

\section{Conclusion}

The proponents of the dominant paradigm believed that the identification of Apollo with the physical sun is an example of a philosophical interpretation of a traditional religious belief. Here it should be borne in mind that 'identification' should be understood as the presence of elements from the solar domain in the complex and accretive entity that developed around a conceptual focus exemplified in the divine name 'Apollo'. This interpretation was either explicitly or implicitly attributed to the Orphic-Pythagorean tradition, most often apparently understood as an application of physical allegoresis on the tenets of traditional religion. In itself this appears to have been an interpretative strategy that excluded the possibility of a traditional understanding of Apollo as in some way related to the physical sun, attributing this association to a later stratum of Greek thought. The scholars who applied this strategy were at least partly motivated by ideological reasons - the preservation of an elevated and pure Hellenic spirit untainted by Oriental mysticism - while their enemy was the solar/naturemythology paradigm that dominated the $19^{\text {th }}$-century discussions on the subject. Their reaction to this easily refutable all-embracing hermeneutic method appears to have been excessive, since the new evaluation of ancient evidence shows that the Apollo-sun interaction was present in Greek ethnographic context from the earliest period (at least from the second half of the $6^{\text {th }}$ century) and cannot be reduced to a philosophical reinterpretation of

\footnotetext{
${ }^{133} \Sigma$ D. 21.654, 2.161 Dilts. For a study of these scholia see Heath 2004, 133-165.

${ }^{134}$ Cook 1925, 729-730. For the Zeus, Ge, Helios triad see Il. 3.103-104, 276-280 (here with 'rivers' and the Erinyes), 19.258-260 (with the Erinyes); cf. E. Med. 746-747 (Helios, Ge and all the gods), Supp. 260-262 (the gods, Ge, Demeter and Helios).

${ }^{135}$ Rhodes and Osborne 2003, 254-258 n. 53.
} 
traditional myth and religion. But even if one might advocate that the earliest identification of Apollo with the sun can be attributed to the early Pythagorean exegesis of traditional beliefs, this claim would require a dismissal of a considerable body of evidence that cannot be subsumed under this category. At the same time, it would require the Orphic-Pythagorean identification to be considered identical in principle with the one attested in Theagenes' physical allegory (and in other similar instances), which seems, in the light of the available evidence, unlikely and unconvincing.

Even though the identification was hardly prevalent, either in the Archaic period or later, it was nevertheless current and could have been used by anyone compelled to adopt and adapt it, whether for religious, literary, philosophical, or any other purpose. Indeed, it was widespread enough to enter the works of such diverse authors as those adduced in this study. Specifically, within the traditional context of myth and religion paradigmatic shifts replacing the sun with Apollo were current, if not particularly widespread. At the same time, it seems that the authors interested in the interpretation of traditional religion in terms of natural philosophy were especially prone to use the Apollo-sun identification in their works, since it was able to provide substantial support for their hermeneutic approach, grounded as it was in the traditional religion itself.

If Apollo was not conceived as having solar connections prior to the earliest attested examples of his assimilation to the sun, than a question should be asked: why did all those who identified Apollo with the celestial body (itself interpreted in anthropomorphic terms by the Greeks) consider the 'pre-identification of Apollo' so much related to the physical sun so as to equate the two? In other words, which characteristics did Apollo have that enabled this identification? Could they be recognized in what we know about the Olympian deity? A concrete answer to this question is hardly ever offered by those who deny the early appearance of Apollo's solar connections. ${ }^{136}$ On the other hand, if Apollo's involvement in the solar domain is accepted as one of his traditional

\footnotetext{
${ }^{136}$ Parker 2011, 77 (cf. Konaris 2016, 294 n. 37) recognizes “a potentiality [for Apollo's identification with the sun] inherent in the Greek conception of deity", but this is only a conclusion based on the undeniable evidence for the identification framed by a dismissal of Apollo's solar connections as part of his early functions. Similarly, Versnel 1994, 318 claims that an original deity undergoing an evolutionary process "must have had a number of characteristics that offer a starting point for linking the influences from outside and the identifications with foreign gods" (this argument certainly also applies to an internal development of a deity). Furley and Bremer 2001, 152 offer a concrete example of such a characteristic: "Apollo's radiant character in iconography and literature predestined him for assimilation with the [sun]". This hardly sounds compelling.
} 
functions, which is in any case the most economical hypothesis, the question becomes superfluous.

\section{Bibliography}

Allen, A. (1993). The Fragments of Mimnermus. Text and Commentary. Stuttgart.

Arnott, W.G. (1997). Menander. Cambridge, MA.

Arvidsson, S. (2006). Aryan Idols. Indo-European Mythology as Ideology and Science. Chicago/London.

Beaulieu, M.-C. (2016). The Sea in the Greek Imagination. Philadelphia.

Beazley, J.D. (1956). Attic Black-Figure Vase-Painters. Oxford.

Bernal, M. (1987). Black Athena. The Afroasiatic Roots of Classical Civilization, Vol. 1: The Fabrication of Ancient Greece, 1785-1985. New Brunswick, NJ.

Boyancé, P. (1966). L'Apollon solaire. In: J. Heurgon, G. Picard, and W. Seston, eds., Mélanges d'archéologie, d'épigraphie et d'histoire offerts à Jérôme Carcopino, Paris, pp. 149-170.

Bremmer, J. (1999). Rationalization and Disenchantment in Ancient Greece. Max Weber among the Pythagoreans and Orphics? In: R. Buxton, ed., From Myth to Reason? Studies in the Development of Greek Thought, Oxford, pp. 71-83.

Bremmer, J. (2011). A Brief History of the Study of Greek Mythology. In: K. Dowden and N. Livingstone, eds., A Companion to Greek Mythology, Oxford/Malden, pp. 527-547.

Burkert, W. (1972). Lore and Science in Ancient Pythagoreanism. Cambridge.

Burkert, W. (1975). Apellai und Apollon. RhM 118, pp. 1-21.

Burkert, W. (1979). Structure and History in Greek Mythology and Ritual. Berkeley/Los Angeles.

Burkert, W. (1985). Greek Religion. Cambridge.

Buxton, R. (2017). Landscapes of the Cyclopes. In: G. Hawes, ed., Myths on the Map. The Storied Landscapes of Ancient Greece, Oxford, pp. 52-64.

Campbell, D.A. (1992). Greek Lyric, Vol. 4: Bacchylides, Corinna, and Others. Cambridge, MA/London.

Cingano, E. (2009). The Hesiodic Corpus. In: F. Montanari, A. Rengakos, and C. Tsagalis, eds., Brill's Companion to Hesiod, Leiden/Boston, pp. 91-130.

Cook, A.B. (1925). Zeus. A Study in Ancient Religion, Vol. 2.1. Cambridge.

Corso, A. (2004). The Art of Praxiteles. The Development of Praxiteles' Workshop and its Cultural Tradition until the Sculptor's Acme. Firenze.

Coxon, A.H. (2009). The Fragments of Parmenides. $2^{\text {nd }}$ ed. Las Vegas.

Croon, J.H. (1952). The Herdsman of the Dead. Utrecht.

Csapo, E. (2005). Theories of Mythology. Malden, MA. 
D’Alessio, G.B. (2005). The Megalai Ehoiai. A Survey of the Fragments. In: R. Hunter, ed., The Hesiodic Catalogue of Women, Cambridge, pp. 176-216.

Davies, M. (1988). Stesichorus' Geryoneis and Its Folk-Tale Origins. CQ 38, pp. 277-290.

Davies, M. (1992). Heracles in Narrow Straits. Prometheus 18, pp. 217-226.

Davies, M. (2006). Unhelpful Helpers. Folk-tale Vestiges in the Homeric Hymns. Prometheus 32, pp. 193-207.

Davies, M., and Finglass, P.J. (2014). Stesichorus, The Poems. Cambridge.

Diggle, J., ed. (1970). Euripides, Phaethon. Cambridge.

Domaradzki, M. (2011). Theagenes of Rhegium and the Rise of Allegorical Interpretation.

Elenchos 32, pp. 205-227.

Dowden, K. (1992). The Uses of Greek Mythology. London/New York.

Edmonds, R.G. (2013). Redefining Ancient Orphism. A Study in Greek Religion. Cambridge/New York.

Edmonds, R.G. (2015). When I Walked the Dark Road of Hades. Orphic Katabasis and the Katabasis of Orpheus. EC 83, pp. 261-279.

Farnell, L.R. (1907). The Cults of the Greek States, Vol. 4. Oxford.

Fiedler, M. (1996). Zur Topographie der Polis Leukas. In: P. Berktold, J. Schmid, and C. Wacker, eds., Akarnanien. Eine Landschaft im antiken Griechenland, Würzburg, pp. 157-168.

Fontenrose, J.E. (1940). Apollo and the Sun-God in Ovid. AJP 61, pp. 429-444.

Fontenrose, J.E. (1974). Python. A Study of Delphic Myth and its Origins. New York.

Fontenrose, J.E. (1978). The Delphic Oracle. Berkeley/Los Angeles/London.

Ford, A. (1999). Performing Interpretation. Early Allegorical Exegesis of Homer. In: M.

Beissinger, J. Tylus, and S. Wofford, eds., Epic Traditions in the Contemporary

World. The Poetics of Community, Berkeley/Los Angeles/London, pp. 33-53.

Ford, A. (2006). The Genre of Genres. Paean and Paian in Early Greek Poetry. Poetica 38, pp. 277-295.

Fowler, R.L. (2013). Early Greek Mythography, Vol. 2. Oxford.

Frame, D. (1978). The Myth of Return in Early Greek Epic. New Heaven/London.

Frame, D. (2009). Hippota Nestor. Washington.

Furley, W., and Bremer, J. (2001). Greek Hymns, Vol. 2. Tübingen.

Gagné, R. (2007). Winds and Ancestors. The Physika of Orpheus. HSCP 103, pp. 1-23.

Gantz, T. (1993). Early Greek Myth. A Guide to Literary and Artistic Sources. Baltimore/London.

Gerber, D.E. (1999). Greek Iambic Poetry. Cambridge.

Gottschalk, H.B., ed. (1980). Heraclides of Pontus. Oxford.

Graf, F. (2003). Initiation. A Concept with a Troubled History. In: D.B. Dodd and C.A.

Faraone, eds., Initiation in Ancient Greek Rituals and Narratives, London/New York, pp. 3-24. 
Graf, F. (2009). Apollo. London/New York.

Griffiths, A. (1999). Euenius the Negligent Nightwatchman (Herodotus 9. 92-6). In: R.

Buxton, ed., From Myth to Reason? Studies in the Development of Greek Thought, Oxford, pp. 169-182.

Gronewald, M., and Daniel, R. (2004a). Ein neuer Sappho-Papyrus. ZPE 147, pp. 1-8.

Gronewald, M., and Daniel, R. (2004b). Nachtrag zum neuen Sappho-Papyrus. ZPE 149, pp. $1-4$.

Hainsworth, B. (1993). The Iliad. A Commentary, Vol. 3: Books 9-12. Cambridge.

Hansen, M.H., and Nielsen, T.H. (2004). An Inventory of Archaic and Classical Poleis. Oxford/New York.

Harrison, J.E. (1908). Helios-Hades. CR 22, pp. 12-16.

Heath, M. (2004). Menander. Oxford/New York.

Hijmans, S.E. (2009). Sol. The Sun in the Art and Religions of Rome. Dissertation, University of Groningen.

Huffman, C.A. (2005). Archytas of Tarentum. Pythagorean, Philosopher and Mathematician King. Cambridge/New York.

Hunter, R. (1986). Apollo and the Argonauts. Two Notes on Ap. Rhod. 2, 669-719. MH 43, pp. 50-60.

Hunter, R. (2005). Introduction. In: R. Hunter, ed., The Hesiodic Catalogue of Women. Cambridge, pp. 1-4.

Hunter, R., and Laemmle, R. (2020). Pulling Apollo Apart. Mnemosyne 73, pp. 377-404.

Iles Johnston, S. (2018). The Story of Myth. Cambridge/London.

Inwood, B. (2001). The Poem of Empedocles. $2^{\text {nd }}$ ed. Toronto/Buffalo/London.

de Jong, I.J.F. (2001). A Narratological Commentary on the Odyssey. Cambridge.

Kagan, D. (1969). The Outbreak of the Peloponnesian War. Ithaca/London.

Kidd, I.G. (1988). Posidonius, Vol. 2: The Commentary. Cambridge.

Kingsley, P. (1995). Ancient Philosophy, Mystery and Magic. Empedocles and Pythagorean Tradition. Oxford/New York.

Kingsley, P. (1996). Empedocles' Two Poems. Hermes 124, pp. 108-111.

Kirk, G.S. (1962). Heraclitus. The Cosmic Fragments. Cambridge.

Kirk, G.S. (1974). The Nature of Greek Myths. London/New York.

Kirk, G.S., Raven, J.E., and Schofield, M. (1983). The Presocratic Philosophers. $2^{\text {nd }}$ ed. Cambridge.

Konaris, M.D. (2010). The Greek Gods in Late Nineteenth- and Early Twentieth-Century German and British Scholarship. In: J. Bremmer and A. Erskine, eds., The Gods of Ancient Greece. Identities and Transformations, Edinburgh, pp. 483-503.

Konaris, M.D. (2011). Apollo in Nineteenth-Century Scholarship. The Case of Karl Otfried Müller. In: M. Haysom and J. Wallensten, eds., Current Approaches to Religion in Ancient Greece, Stockholm, pp. 13-22. 
Konaris, M.D. (2016). The Greek Gods in Modern Scholarship. Oxford.

Krauskopf, I. (2013). Gods and Demons in the Etruscan Pantheon. In: J.M. Turfa, ed., The Etruscan World, Abingdon, pp. 513-538.

Kupreeva, I. (2009). Heraclides On the Soul (?) and its Ancient Readers. In: W.W. Fortenbaugh and E.E. Pender, eds., Heraclides of Pontus. Discussion, New Brunswick/London, pp. 93-138.

Lamberton, R. (1986). Homer the Theologian. Neoplatonist Allegorical Reading and the Growth of the Epic Tradition. Berkeley.

Lamberton, R. (1997). Homer in Antiquity. In: I. Morris and B. Powell, eds., A New Companion to Homer, Leiden, pp. 33-54.

Linforth, I.M. (1941). The Arts of Orpheus. Berkeley.

Loraux, N. (2000). Born of the Earth. Myth and Politics in Athens. Ithaca/London.

Mansfeld, J. (1990). Studies in the Historiography of Greek Philosophy. Assen/Maastricht.

Mansfeld, J., and Runia, D.T. (2010). Aëtiana. The Method and Intellectual Context of a Doxographer, Vol. 3. Leiden/Boston.

Mondi, R. (1990). Greek Mythic Thought in the Light of the Near East. In: L. Edmunds, ed., Approaches to Greek Myth, Baltimore/London, pp. 142-198.

Moreau, A. (1996). Quand Apollon devint Soleil. In: A. Bakhouche, A. Moreau, and J.C. Turpin, eds., Les astres. Actes du Colloque International de Montpellier, 23-25 mars 1995, Montpellier, pp. 11-35.

Morris, S. (2001). The Towers of Ancient Leukas. Results of a Topographic Survey, 19911992. Hesperia 70, pp. 285-347.

Müller, K.O. (1824). Geschichten hellenischer Stämme und Städte, Vol. 2. Breslau.

Naddaf, G. (2009). Allegory and the Origins of Philosophy. In: W. Wians, ed., Logos and Muthos. Philosophical Essays in Greek Literature, Albany, pp. 99-131.

Nagy, G. (1973). Phaethon, Sappho's Phaon, and the White Rock of Leukas. HSCP 77, pp. 137-177.

Nakassis, D. (2004). Gemination at the Horizons. East and West in the Mythical Geography of Archaic Greek Epic. TAPhA 134, pp. 215-233.

Osborne, R. (2000). The Athenian Empire. $4^{\text {th }}$ ed. London.

Parker, R. (2011). On Greek Religion. Ithaca/London.

Plant, I.M. (2004). Women Writers of Ancient Greece and Rome. Norman.

Reiche, H.A.T. (1993). Heraclides' Three Soul-Gates. Plato Revised. TAPhA 123, pp. 161180.

Rhodes, P.J., and Osborne, R. (2003). Greek Historical Inscriptions 404-323 BC. Oxford/New York.

Riedweg, C. (2005). Pythagoras. His Life, Teaching, and Influence. Ithaca/New York.

Robertson, N. (2010). Religion and Reconciliation in Greek Cities. The Sacred Laws of Selinus and Cyrene. Oxford. 
Roscher, W.H., ed. (1884-1890). Ausführliches Lexikon der griechischen und römischen Mythologie, Vol. 1. Leipzig.

Rotstein, A. (2010). The Idea of Iambos. Oxford.

Russell, D.A., and Wilson, N.G. (1981). Menander Rhetor. Oxford.

Russo, J., Fernández-Galiano, M., and Heubeck, A. (1992). A Commentary on Homer's Odyssey, Vol. 3: Books xvii-xxiv. Oxford.

Rutherford, I. (2015). Stesichorus the Romantic. In: P.J. Finglass and A. Kelly, eds., Stesichorus in Context, Cambridge, pp. 98-108.

Seaford, R. (2005). Mystic Light in Aeschylus' Bassarai. CQ 55, pp. 602-606.

Sick, D.H. (2004). Mit(h)ra(s) and the Myths of the Sun. Numen 51, pp. 432-467.

Simon, E. (1983). Festivals of Attica. Madison.

Solmsen, F. (1980). Empedocles' Hymn to Apollo. Phronesis 25, pp. 219-227.

Solomon, J. (1994). Apollo and the Lyre. In: J. Solomon, ed., Apollo. Origins and Influences, Tucson/London, pp. 37-46.

Tsagalis, C. (2017). Early Greek Epic Fragments, Vol. 1: Antiquarian and Genealogical Epic. Berlin/Boston.

van der Valk, M. (1958). On Apollodori Bibliotheca. REG 71, pp. 100-168.

Vergados, A. (2013). A Commentary on the Homeric Hymn to Hermes. Berlin/Boston.

Versnel, H.S. (1994). Inconsistencies in Greek and Roman Religion, Vol. 2: Transition and Reversal in Myth and Ritual. $2^{\text {nd }}$ ed. London/New York/Köln.

Walcot, P. (1979). Cattle Raiding, Heroic Tradition, and Ritual. The Greek Evidence, HR 18, pp. 326-351.

Wernicke, K. (1896). Augeias 1. RE 2.4, cols. 2306-2310.

West, M.L. (1974). Studies in Greek Elegy and Iambus. Berlin/New York.

West, M.L. (1983a). The Orphic Poems. Oxford.

West, M.L. (1983b). Tragica VI, BICS 30, pp. 63-82.

West, M.L. (1990). Studies in Aeschylus. Stuttgart.

West, M.L. (2007). Indo-European Poetry and Myth. Oxford.

von Wilamowitz-Moellendorff, U. (1908). Greek Historical Writing, and Apollo. Oxford. Zhmud, L. (2012). Pythagoras and the Early Pythagoreans. Oxford. 